\title{
A Bioinspired Peptide in TIR Protein as Recognition Molecule on Electrochemical Biosensors for the Detection of E. coli O157:H7 in an Aqueous Matrix
}

\author{
Jose Luis Ropero-Vega ${ }^{1, *(\mathbb{D})}$, Joshua Felipe Redondo-Ortega ${ }^{1, * \mathbb{D}}$, Yuli Juliana Galvis-Curubo ${ }^{1}$, \\ Paola Rondón-Villarreal ${ }^{2} \mathbb{D}$ and Johanna Marcela Flórez-Castillo ${ }^{1}$ (D) \\ 1 Facultad de Ciencias Exactas, Naturales y Agropecuarias, Ciencias Básicas y Aplicadas Para la \\ Sostenibilidad-CIBAS, Universidad de Santander, Calle 70 No. 55-210, \\ Bucaramanga C.P. 680003, Santander, Colombia; julianagalvis20@outlook.com (Y.J.G.-C.); \\ johanna.florez@udes.edu.co (J.M.F.-C.) \\ 2 Facultad de Ciencias de la Salud, Grupo de Investigación en Biología Molecular y Biotecnología, \\ Universidad de Santander, Calle 70 No. 55-210, Bucaramanga C.P. 680003, Santander, Colombia; \\ diseno.molecular@udes.edu.co \\ * Correspondence: jose.ropero@udes.edu.co (J.L.R.-V.); jredondo@mail.udes.edu.co (J.F.R.-O.); \\ Tel.: +57-7-6516500 (ext. 1665) (J.L.R.-V.)
}

Citation: Ropero-Vega, J.L.; Redondo-Ortega, J.F.; Galvis-Curubo, Y.J.; Rondón-Villarreal, P.;

Flórez-Castillo, J.M. A Bioinspired Peptide in TIR Protein as Recognition Molecule on Electrochemical Biosensors for the Detection of E. coli O157:H7 in an Aqueous Matrix. Molecules 2021, 26, 2559. https:// doi.org/10.3390/molecules26092559

Academic Editors: Grzegorz D. Sulka and Robert Bogdanowicz

Received: 27 February 2021

Accepted: 20 April 2021

Published: 28 April 2021

Publisher's Note: MDPI stays neutra with regard to jurisdictional claims in published maps and institutional affiliations.

Copyright: (c) 2021 by the authors. Licensee MDPI, Basel, Switzerland. This article is an open access article distributed under the terms and conditions of the Creative Commons Attribution (CC BY) license (https:// creativecommons.org/licenses/by/ $4.0 /)$.
Abstract: Currently, the detection of pathogens such as Escherichia coli through instrumental alternatives with fast response and excellent sensitivity and selectivity are being studied. Biosensors are systems consisting of nanomaterials and biomolecules that exhibit remarkable properties such as simplicity, portable, affordable, user-friendly, and deliverable to end-users. For this, in this work we report for the first time, to our knowledge, the bioinformatic design of a new peptide based on TIR protein, a receptor of Intimin membrane protein which is characteristic of $E$. coli. This peptide (named PEPTIR-1.0) was used as recognition element in a biosensor based on AuNPs-modified screen-printed electrodes for the detection of E. coli. The morphological and electrochemical characteristics of the biosensor obtained were studied. Results show that the biosensor can detect the bacteria with limits of detection and quantification of 2 and $6 \mathrm{CFU} / \mathrm{mL}$, respectively. Moreover, the selectivity of the system is statistically significant towards the detection of the pathogen in the presence of other microorganisms such as P. aeruginosa and S. aureus. This makes this new PEPTIR-1.0 based biosensor can be used in the rapid, sensitive, and selective detection of E. coli in aqueous matrices.

Keywords: pathogen; PEPTIR-1.0; screen-printed electrodes; gold nanoparticles; electrodeposition; limit of detection; selectivity

\section{Introduction}

The World Health Organization (WHO) highlights the need for constant monitoring and control of pathogenic microorganisms such as Escherichia coli, because strains such as the Shiga toxin-producing pathotype cause severe diseases in humans after ingestion through contaminated food or water. This represents a tremendous public health problem [1,2]. Several methods have been developed to detect E. coli O157:H7 in aqueous matrices, including traditional culture with selective media [3], serotyping with specific antibodies against $\mathrm{O} 157$ and $\mathrm{H} 7$ antigens [4,5], the amplification of specific genes by PCR [6,7], or hybridization of virulence genes by DNA microarrays [8]. However, these methods are limited by high cost, use of specialized equipment, long sample processing time and the need for personnel trained in sample handling and analysis. For this reason, it is necessary to design devices that are affordable, sensitive, specific, user-friendly, rapid and robust, equipment-free, and deliverable to end-users in order to facilitate the monitoring of the microbiological quality of aqueous systems [9]. 
Biosensors are instruments consist of a molecule of biological nature, also called biological recognition element, and a physicochemical transducer [10]. The recognition element is responsible for interacting biochemically with the analyte of interest and gives the specificity to the biosensor. In principle, any biological structure with this capacity can be used. Whole cells, subcellular organelles, fine sections of cellular tissues, membrane receptors, nucleic acids (DNA or RNA), antibodies, enzymes, and peptides are commonly used [11-13]. On the other hand, the transducer is responsible for transform the biochemical interaction between the recognition element and the analyte into a quantifiable signal [14-16]. In electrochemical biosensors, this quantifiable signal commonly consists of a current or changes in the impedance of the biosensor/analyte interface. On this devices, transducers are commonly based on conductive materials like carbon nanostructures and metallic nanoparticles [17]. In this sense, biosensors become an interesting alternative method for the detection of microorganisms such as E. coli in aqueous matrices.

Recently, peptide-based biosensors have been widely studied in pathogen detection and disease diagnosis due to their sensitivity, low cost, and specificity [18-22]. These devices are probably the most versatile systems due to the physicochemical properties of the peptides. These molecules are typically composed of 10 to 100 amino acids and adopt secondary structures such as $\alpha$-helix, $\beta$-sheet and loops. These tridimensional structures can interact with analytes of interest such as ions, molecules, membranes of microorganisms or whole cells. The peptide-analyte interaction occurs commonly through non-covalent intermolecular interactions such as hydrophobic interactions, hydrogen bonds, electrostatic interactions, etc. [23]. Furthermore, peptides can be designed in such a way that they can replace the domains of interest of some proteins, such as specific regions of antibodies, enzymes, or protein receptor binding sites [24]. Thereby, it is possible to obtain shorter molecules with higher stability and specificity.

The aim of this study was to design and evaluate a peptide analogous to the TIR protein (Translocated Intimin Receptor) as recognition molecule in electrochemical biosensors for the detection of E. coli in aqueous matrices. The TIR protein is a molecule expressed by the TIR gene of E. coli and is involved in the pathogenesis mechanism of enterohemorrhagic and enteropathogenic serotypes towards the outer membrane of enterocytes. TIR interacts through the extracellular domain of $E$. coli with the protein Intimin which is an outer membrane adhesin encoded by the eaeA gene, widely studied due to its role in the pathogenesis of E. coli [25]. This protein was considered in this study as a target receptor for the detection of this pathogen.

It is important to highlight that this is the first study in which bioinformatics tools and electrochemical techniques are integrated to design peptides analogous to the TIR protein and used as recognition molecules for the electrochemical detection of E. coli.

\section{Results and Discussion}

\subsection{Selection of the TIR Protein Interaction Sequence Using Bioinformatics Tools}

Figure 1 shows the domains of possible interaction between the TIR and Intimin proteins. TIR protein binding domain has 20 amino acids responsible for interaction with the Intimin protein. Within these amino acids are four acidic amino acids (one Glu residue and three Asp residues) and two Lys residues, which confers a net negative charge on the binding domain. Additionally, seven hydrophobic residues are observed, suggesting that hydrophobic and electrostatic interactions are predominant in the TIRIntimin interaction [26]. 


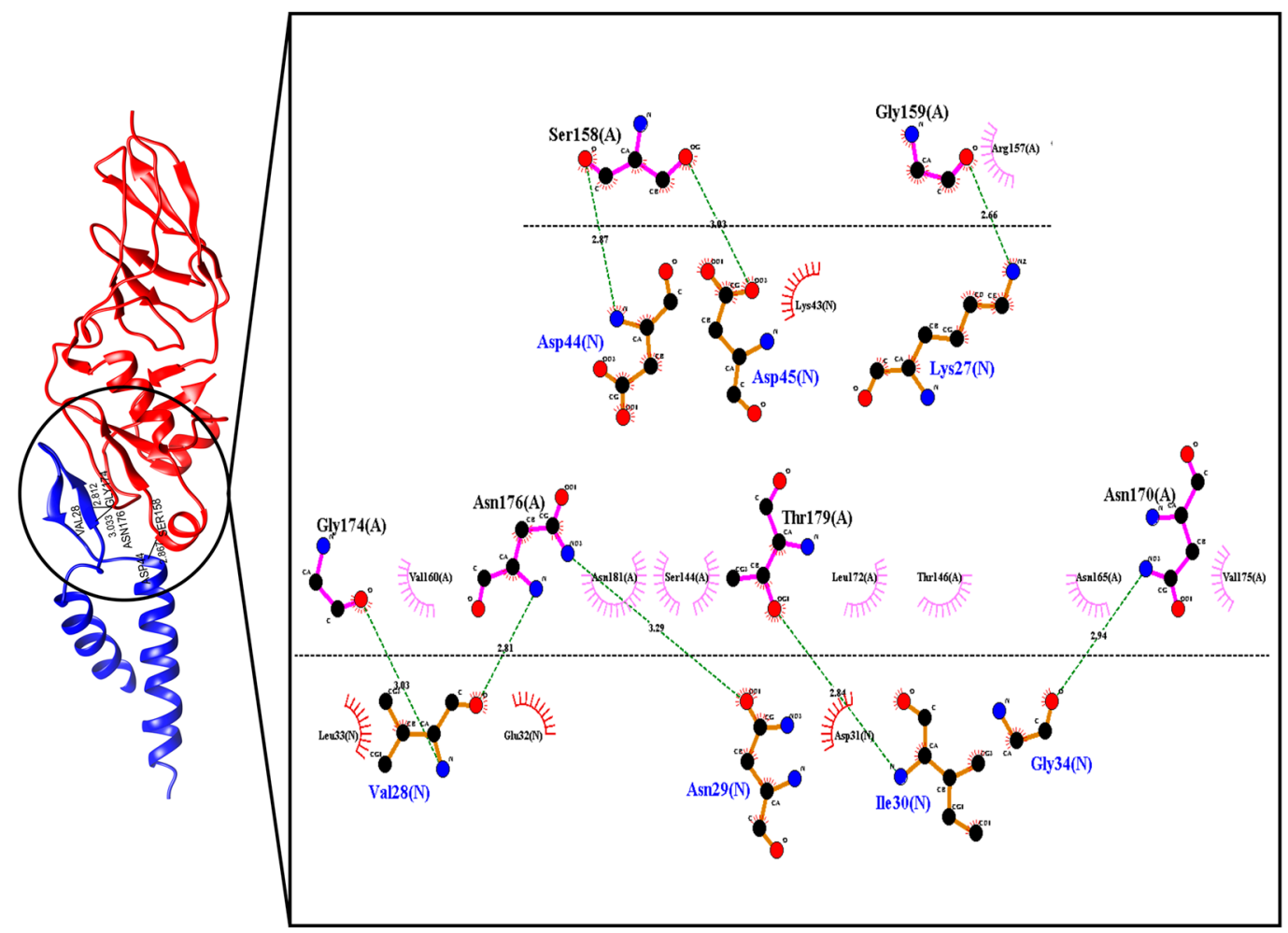

Figure 1. Crystal structure of the interaction between TIR proteins (N-Blue chain) and Intimin (A-Red chain), obtained from the PDB 2ZQK model.

The 20 amino acids of the binding domain between TIR-Intimin (QKVNIDELGNAIPSGVLKDD) were used to design the peptide to be immobilized in the electrochemical biosensor. 3D-structure of peptide was obtained using PEP-FOLD program. Figure 2 shows the five most probable models which were compared with the binding domain of the TIR protein of the 2ZQK model using the PyMol program. Models 1, 3 and 5 present a conserved structure where it can be seen two $\beta$-sheets similar to those seen in the TIR protein. Otherwise, models 2 and 4 present an $\alpha$-helix structure different from the TIR protein structure.

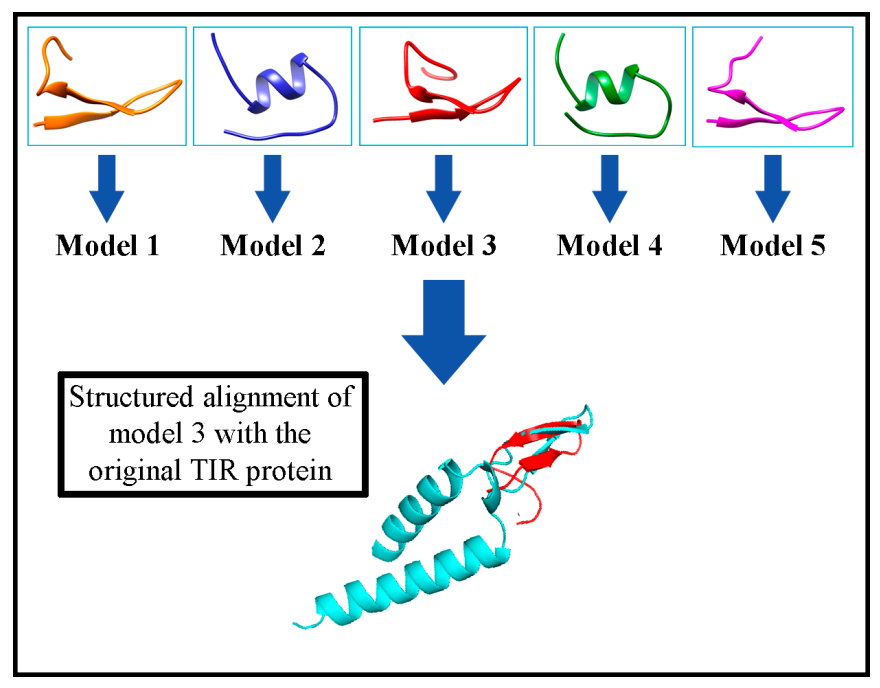

Figure 2. Three-dimensional structure of five models obtained from the sequence: QKVNIDELGNAIPSGVLKDD with the PEP-FOLD tool. 
Root-mean-square-deviation of atomic positions (RMSD) values were determined to quantify the structural differences between the models found by PEP-FOLD and the binding domain of the TIR protein (Table 1).

Table 1. RMSD values associated with the five models obtained with PEP-FOLD.

\begin{tabular}{cc}
\hline Model & RMSD \\
\hline 1 & 4834 \\
2 & 7722 \\
3 & 4252 \\
4 & 8359 \\
5 & 6011 \\
\hline
\end{tabular}

Models 2 and 4 show the highest RMSD values due to the $\alpha$-helix structure acquired in the IDELGNA amino acid region. Model 5 acquired a disordered structure at the Cterminal, which is distant from the TIR protein loop. For this reason, it shows a high RMSD value despite having a similar structure to the TIR protein. Model 3 presented the lowest RMSD value and was therefore selected to perform the molecular docking simulations.

\subsection{Selection of Ligands and Molecular Docking between the Peptide and the Intimin Protein}

The selected recognition molecule was named as $N$-chain to perform a molecular docking analysis together with the original structure of the Intimin protein (Figure 3), identified as chain A. Using the FlexPepDock platform, the site of interaction of the peptide based on the TIR protein in the extracellular domain of the Intimin protein was confirmed.

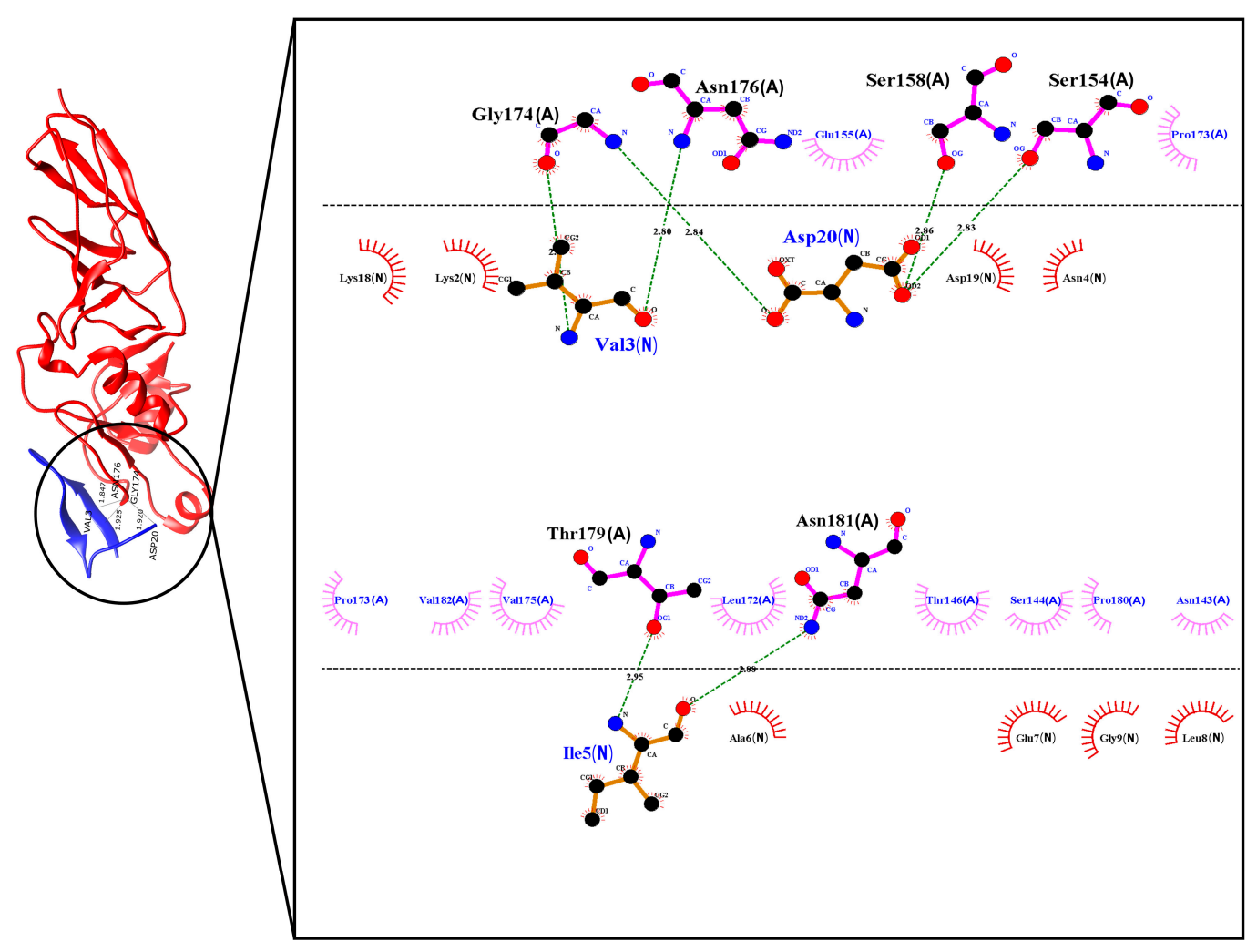

Figure 3. Complex between the peptide model obtained with PEP-FOLD and the original structure of the Intimin protein, predicted by the FlexPepDock program.

From the 200 models calculated by the FlexPepDock program, the five models with the best Rosetta and RMSD energy score values were further analyzed using the software 
LigPlot+ [27], the Prodigy Haddock program [28] and the Rosetta InterfaceAnalyzer protocol [29]. The results obtained are shown in Table 2. The number and type of intermolecular contacts were defined within the distance limit of $5.5 \AA$ A. dG_Sep gives the binding energy calculated as the change in Rosetta energy when the interface forming chains are separated versus when they are complexed (Rosetta energy units). dSASA indicates the solvent accessible area buried at the interface. Per_res_energy is the average energy of each residue at the interface (Rosetta energy units).

Table 2. Interaction parameters between peptide models and the Intimin protein obtained with the FlexPepDock and Prodigy Haddock programs.

\begin{tabular}{|c|c|c|c|c|c|c|}
\hline Model & $\begin{array}{c}\Delta \mathrm{G} \\
(\mathrm{Kcal} / \mathrm{mol})^{1}\end{array}$ & $\begin{array}{c}\mathrm{Kd} \\
(\mathrm{mol} / \mathrm{L})^{2}\end{array}$ & Interactions & $\begin{array}{c}\text { dG_Sep } \\
\text { (Rosetta Energy) }\end{array}$ & $\begin{array}{c}\text { dSASA_int } \\
\left(\AA^{2}\right)\end{array}$ & $\begin{array}{l}\text { Per_res_Energy } \\
\text { (Rosetta Energy) }\end{array}$ \\
\hline TIR (Original) & -11.50 & $3.7 \times 10^{-9}$ & 62 & -11.36 & 1174.01 & +2.148 \\
\hline 3.1 & -10.9 & $9.6 \times 10^{-9}$ & 52 & -25.08 & 984.05 & -1.873 \\
\hline 3.2 & -10.6 & $1.6 \times 10^{-8}$ & 53 & -25.19 & 981.98 & -1.751 \\
\hline 3.3 & -10.8 & $1.3 \times 10^{-8}$ & 47 & -24.99 & 890.17 & -1.845 \\
\hline 3.4 & -10.8 & $1.2 \times 10^{-8}$ & 49 & -22.52 & 998.71 & -1.568 \\
\hline 3.5 & -10.5 & $2.1 \times 10^{-8}$ & 54 & -21.99 & 963.32 & -1.745 \\
\hline
\end{tabular}

${ }^{1}$ Predicted value of the free energy of binding. ${ }^{2}$ Predicted value of the dissociation constant $(\mathrm{Kd})$ calculated from $\Delta \mathrm{G}=\mathrm{RT} \ln (\mathrm{Kd})$, where $\mathrm{R}$ is the ideal gas constant $\left(\mathrm{kcal} \mathrm{K}^{-1} \mathrm{~mol}^{-1}\right)$ and $\mathrm{T}$ the temperature $(\mathrm{K})$.

The interactions predicted by LigPlot+ showed that the designed peptide and TIR protein had the same binding region when interacting with the Intimin protein. Moreover, even though the interaction occurs with a ligand of only 20 amino acids, it manages to generate more than $80 \%$ of the number of intermolecular contacts within the $5.5 \AA$ distance limit that can occur at the peptide and Intimin interface, with a total of 52 interfacial contacts. Furthermore, model 3.1 generated by the FlexPepDock program presents values of binding affinity and dissociation constant close to the values of the original model, as shown in Table 2. Moreover, for the parameters obtained with the InterfaceAnalyzer protocol, i.e., the binding energy, the solvent accessible area buried at the interface, and the average energy of each residue at the interface, the values obtained for the five best models of peptide-Intimin complexes were better than the values obtained for the TIR-Intimin complex.

These results are promising, and it can be inferred that, although the peptide model is much smaller than the original ligand, the interactions that define the binding with the receptor molecule are mainly concentrated in its 20 residues and predict the ability of the peptide to interact appropriately in vitro with the protein Intimin. Therefore, this peptide was selected as a recognition molecule (designated as PEPTIR-1.0) for the subsequent preparation of the electrochemical biosensor.

\subsection{Preparation and Characterization of the Biosensor}

\subsubsection{Electrodeposition of Gold Nanoparticles (AuNPs)}

The AuNPs were deposited on the working electrode (WE) of the screen-printed electrodes (SPE, Italsens) using the chronoamperometry (CA) technique. An aqueous

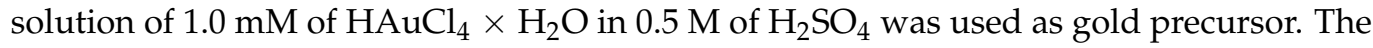
potentials selected for $\mathrm{CA}$ were based on the result obtained by linear sweep voltammetry. The effect of potential and time used in CA was evaluated on the preliminary detection of E. coli (EC, $500 \mathrm{CFU} / \mathrm{mL}$ ). The results of the analyses are shown in Figure 4.

Linear sweep voltammogram (Figure $4 a$ ) shows an onset reduction potential to a close value of $+0.6 \mathrm{~V}$ with a maximum current at $+0.4 \mathrm{~V}$ which is maintained until $-0.2 \mathrm{~V}$. Below this potential, the reduction of the medium to produce hydrogen gas begins [30]. Given the above, the potentials selected for the electrodeposition of gold by CA were below $+0.05 \mathrm{~V}$ to ensure the reduction of the gold precursor. All the CA curves (Figure $4 \mathrm{~b}-\mathrm{d}$ ) exhibited the typical shape and current values for an electrochemical reduction process [31]. It is noteworthy that the reduction currents reach a steady state value close to $-10 \mu \mathrm{A}$ after 
about $20 \mathrm{~s}$ in all cases. The currents were slightly more negative when the most negative reduction potentials ( -0.15 and $-0.25 \mathrm{~V}$, blue and rose lines, respectively) were applied. On the other hand, it was not observed a significant difference in the currents obtained when applying the potentials of +0.05 and $-0.05 \mathrm{~V}$ at the different electrodeposition times.
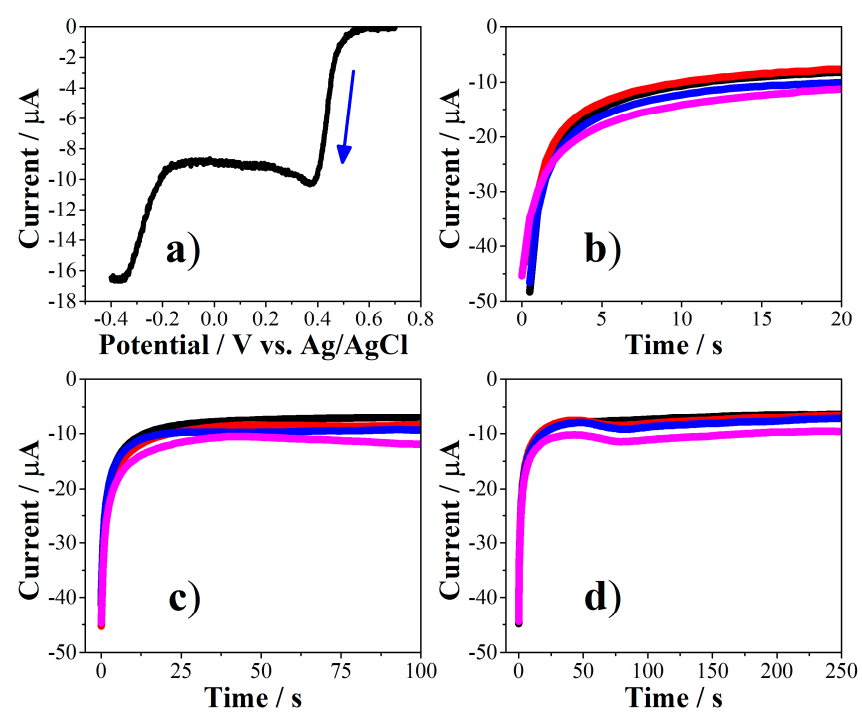

Figure 4. Electrodeposition of gold nanoparticles (AuNPs) on screen-printed electrodes. Linear sweep voltammogram $(5.0 \mathrm{mV} / \mathrm{s})$ of gold precursor (a). Current vs. time curves at $20 \mathrm{~s}(\mathbf{b}), 100 \mathrm{~s}(\mathbf{c})$ and $250 \mathrm{~s} \mathrm{(d).} \mathrm{The} \mathrm{applied} \mathrm{potentials} \mathrm{were}+0.05 \mathrm{~V}$ (black lines), $-0.05 \mathrm{~V}$ (red lines), $-0.15 \mathrm{~V}$ (blue lines) and $-0.25 \mathrm{~V}$ (rose lines) in all cases.

The surface of the WE was analyzed by scanning electron microscopy to evaluate the size and distribution of the gold nanoparticles formed. The results are shown in Figure 5.
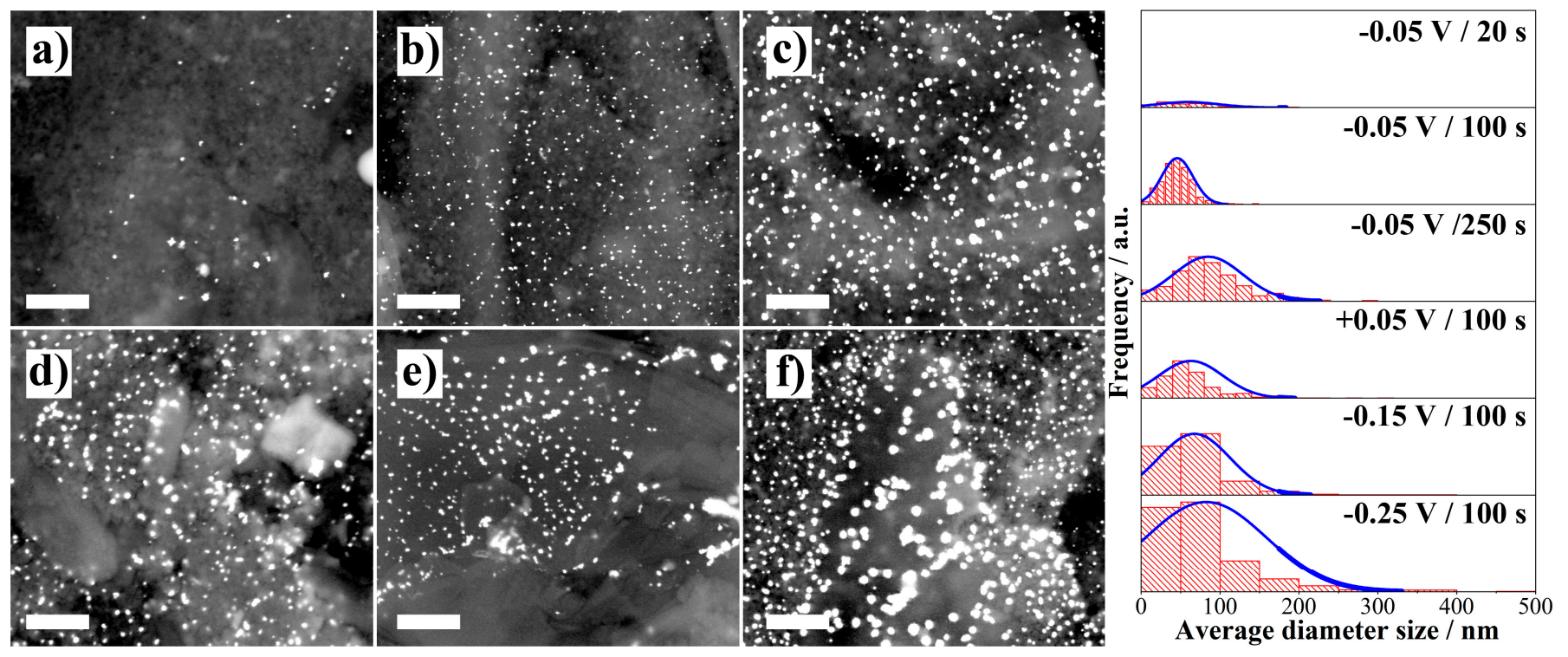

Figure 5. Scanning electron microscopy (SEM) results. Left: Micrographs of the working electrodes with AuNPs prepared by electrodeposition at a constant potential of $-0.05 \mathrm{~V}$ during (a) $20 \mathrm{~s}$, (b) $100 \mathrm{~s}$ and (c) $250 \mathrm{~s}$, and at a constant time of $100 \mathrm{~s}$ at $(\mathbf{d})+0.05 \mathrm{~V},(\mathbf{e})-0.15 \mathrm{~V}$ and (f) $-0.25 \mathrm{~V}$. All images were recorded with backscattered electron detector (BSED). 50,000 X, scale bar $1 \mu \mathrm{m}$. Right: Histograms of the average diameter size of AuNPs for each condition.

The effect of increasing the electrodeposition time at a constant potential of $-0.05 \mathrm{~V}$ (Figure $5 \mathrm{a}-\mathrm{c}$ ) showed the formation of a greater number of particles. As expected according 
to the CA results, the nucleation stage occurs during first $20 \mathrm{~s}$ followed by the growth stage, reaching average particle sizes of around $90 \mathrm{~nm}$ at $250 \mathrm{~s}$. In the nucleation stage, few particles are formed while there is a good distribution and size of them in a time of $100 \mathrm{~s}$ (see histograms in right of Figure 5). On the other hand, it was observed a large size distribution when different potentials were applied at a constant time of $100 \mathrm{~s}$ (Figure $5 \mathrm{~d}-$ $\mathrm{f}$ and histograms). It is worth noting that at electrodeposition potentials of -0.15 and $-0.25 \mathrm{~V}$, many particles are observed but with a very varied size distribution.

The definition of the electrodeposition variables of AuNPs by CA was carried out with the implementation of a factorial design of two factors in the detection of $E$. coli ( $500 \mathrm{CFU} / \mathrm{mL}$, concentration used as reference). This design allows to study the simultaneous effect of the reduction applied potential and the electrodeposition time and how these factors influence the response of the entire biosensor construction and the detection of E. coli. Square wave voltammetry (SWV) was used to evaluate the changes in the electrochemical response of the biosensor in the presence of $\left[\mathrm{Fe}(\mathrm{CN})_{6}\right]^{-3 /-4}$ couple as redox indicator. The PEPTIR-1.0 was used as recognition element and $10 \mu \mathrm{L}$ of an aqueous solution of $500 \mathrm{nM}$ were used for its immobilization on the WE. The results of the effect of the electrodeposition potential at a constant time of $100 \mathrm{~s}$ and varying the electrodeposition time at a constant potential of $-0.05 \mathrm{~V}$ is shown in Figure 6. The results of the other potentials and times are found in supplementary information (Figures S1 and S2).
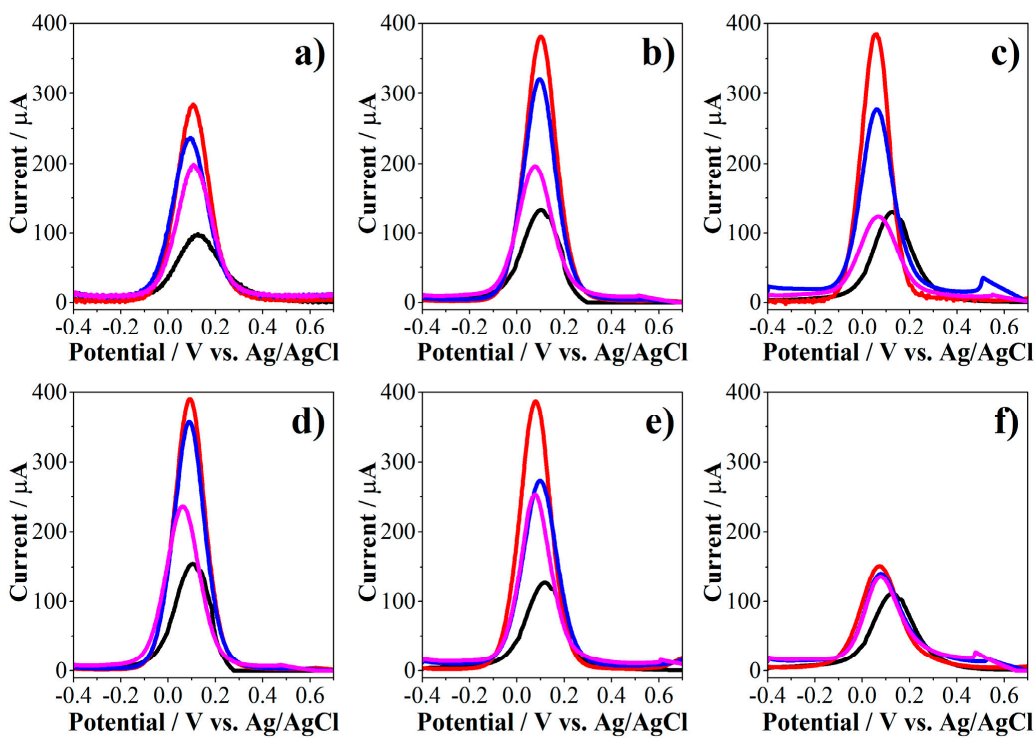

Figure 6. SWV results of the effect of varying the electrodeposition time for (a) $20 \mathrm{~s}$, (b) $100 \mathrm{~s}$ and (c) $250 \mathrm{~s}$ at a constant potential of $-0.05 \mathrm{~V}$ and varying the applied potential at (d) $+0.05 \mathrm{~V}$, (e) $-0.15 \mathrm{~V}$ and (f) $-0.25 \mathrm{~V}$ at constant time of $100 \mathrm{~s}$ in the electrodeposition of AuNPs towards the detection of E. coli (500 CFU/mL). The curves correspond to SPE (black lines), SPE/AuNPs (red lines), SPE/AuNPs/PEP (blue lines) and SPE/AuNPs/PEP/EC (rose lines) in all cases. $10 \mathrm{mM}$ of $\left[\mathrm{Fe}(\mathrm{CN})_{6}\right]^{-3 /-4}$ in $0.1 \mathrm{M}$ of $\mathrm{KCl}$ aqueous solution.

The voltammograms in Figure 6 show an increase in the current of the AuNPsmodified screen-printed electrodes (SPE/AuNPs, red lines) compared to the unmodified electrode (SPE, black lines). This is due to the improvement in the charge transfer reaction of $\left[\mathrm{Fe}(\mathrm{CN})_{6}\right]^{-3 /-4}$ couple on the electrode as a consequence of the formation of nanoparticles with high electroactivity. Moreover, there was no significant increase in current for SPE/AuNPs above $100 \mathrm{~s}$ of electrodeposition, probably due to the electrode is saturated in that condition (Figure $6 \mathrm{~b}, \mathrm{c}$ ). It is worth clarifying that the expected behavior of the electrode involves a reduction of the current in the immobilization of PEPTIR-1.0 and detection of E. coli stages. This is because during each of these stages, the surface of the 
working electrode loses electroactivity. Thereby, the oxidation-reduction reactions of the $\left[\mathrm{Fe}(\mathrm{CN})_{6}\right]^{-3 /-4}$ couple will be restricted.

The difference between the current of the biosensor (SPE/AuNPs/PEP, blue lines) and the detection of the microorganism (SPE/AuNPs/PEP/EC, rose lines) is notably higher at potentials of electrodeposition of $+0.05 \mathrm{~V}$ and $-0.05 \mathrm{~V}$ at $100 \mathrm{~s}$ than at other potentials and times. Finally, the changes in the modification of the electrode to a reduction potential of $-0.25 \mathrm{~V}$ are not marked.

Normalized currents $\left(\Delta \mathrm{I}_{\text {Normalized }}\right)$ were obtained from voltammograms by using the maximum current value of SPE/AuNPs/PEP and the maximum current value of $\mathrm{SPE} / \mathrm{AuNPs} / \mathrm{PEP} / \mathrm{EC}$. The results obtained are shown in Table S1 (see supplementary information). The values in Table S1 were graphed to evaluate any simultaneous interaction between de potential and time as AuNPs electrodeposition variables on the biosensor response and the results are shown in Figure 7.

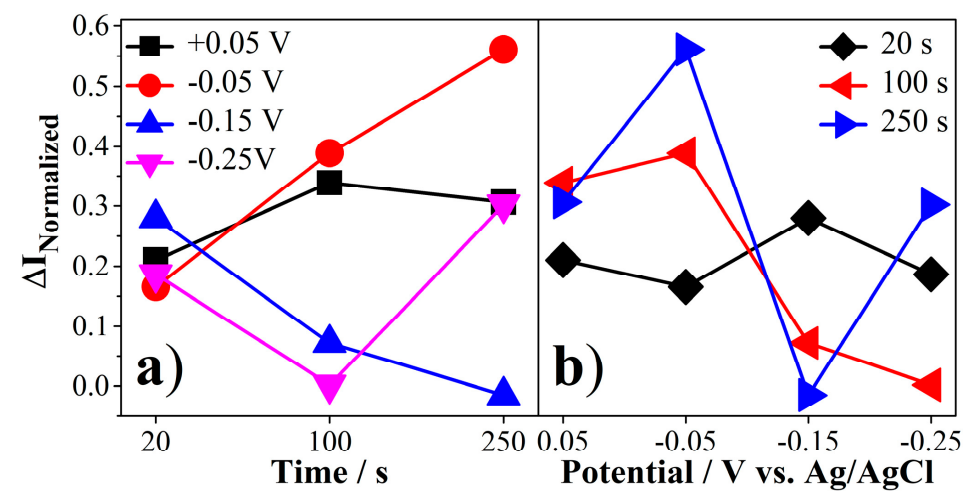

Figure 7. Two-factor factorial design results in the electrodeposition of AuNPs. (a) Normalized current vs. time of electrodeposition at $+0.05 \mathrm{~V}(\mathbf{\square}),-0.05 \mathrm{~V}(\bullet),-0.15 \mathrm{~V}(\mathbf{\Delta})$ and $-0.25 \mathrm{~V}(\mathbf{\nabla})$.

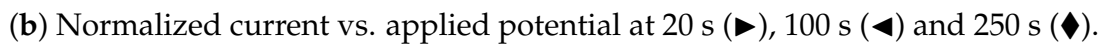

The results obtained for these variables show that they have an explicit influence on the response of the biosensor, i.e., the potential and time in chronoamperometry are independent variables but present an interaction which indicated that they are significantly influenced by each other. Moreover, a favorable trend was observed over time at a reduction potential of $-0.05 \mathrm{~V}$ (Figure $7 \mathrm{a}$, red curve). However, the tendency of the normalized current at $250 \mathrm{~s}$ is to decrease for all other potentials (Figure $7 \mathrm{~b}$, blue curve). Considering the above, it was established that a potential of $-0.05 \mathrm{~V}$ and a time of $100 \mathrm{~s}$ are optimal to carry out the deposition of AuNPs by electrochemical reduction in this biosensor.

\subsubsection{Immobilization of PEPTIR-1.0 on AuNPs-Modified Screen-Printed Electrodes}

The PEPTIR-1.0 peptide (sequence QKVNIDELGNAIPSGVLKDD) has a cysteine included in the $N$-terminal region of the chain. Thus, the immobilization of PEPTIR-1.0 on the surface of AuNPs-modified screen-printed was performed by self-assembly of the former through the thiol group on the surface of the AuNPs. The changes generated in the electrochemical properties of the working electrode (WE) were evaluated by cyclic voltammetry $(\mathrm{CV})$, square wave voltammetry $(\mathrm{SWV})$ and electrochemical impedance spectroscopy (EIS) by using $\left[\mathrm{Fe}(\mathrm{CN})_{6}\right]^{-3 /-4}$ couple as redox indicator and the results are shown in Figure 8. 

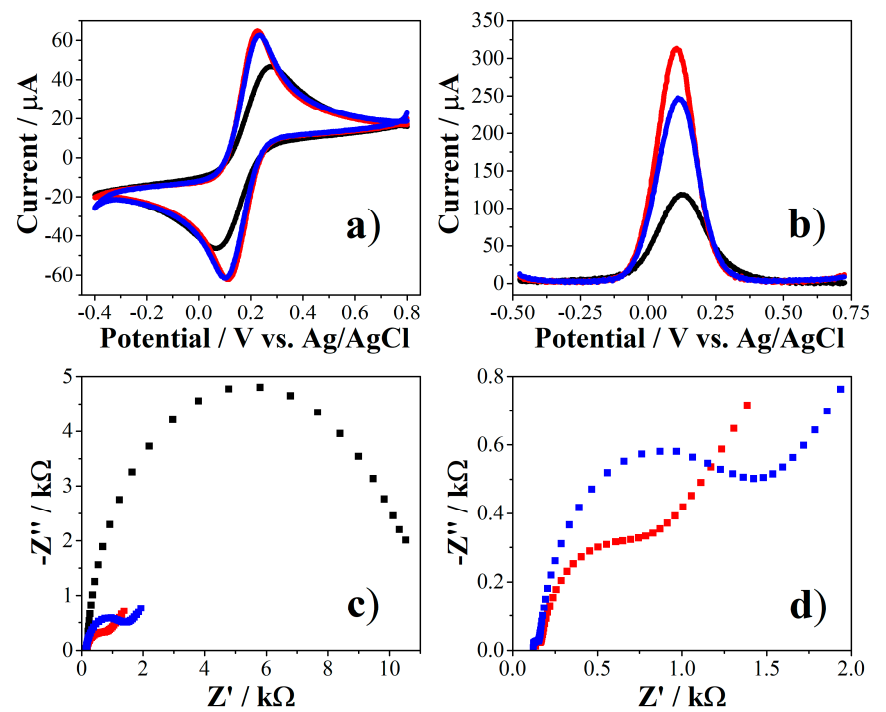

Figure 8. Electrochemical characterization of the screen-printed electrodes modified with AuNPs and PEPTIR-1.0 by CV (a), SWV (b) and EIS (c) during the construction of the biosensor. In all cases the black, red and blue lines or dots correspond to SPE, SPE/AuNPs and SPE/AuNPs/PEP, respectively. EIS results for SPE/AuNPs and SPE/AuNPs/PEP are presented expanded in (d) for clarity. $10 \mathrm{mM}$ of $\left[\mathrm{Fe}(\mathrm{CN})_{6}\right]^{-3 /-4}$ in $0.1 \mathrm{M}$ of $\mathrm{KCl}$ aqueous solution for $\mathrm{CV}$ and SWV. $2.0 \mathrm{mM}$ of $\left[\mathrm{Fe}(\mathrm{CN})_{6}\right]^{-3 /-4}$ for EIS.

As mentioned in the previous section, electrodeposition of AuNPs improves electrical transport properties of the surface of electrode. This was evidenced by CV and SWV as an increase in the current together with a decrease in the difference of the oxidationreduction potentials of the $\left[\mathrm{Fe}(\mathrm{CN})_{6}\right]^{-3 /-4}$ couple in CV results (red curves in Figure $8 a, b$ ). Meanwhile, the Nyquist diagram in Figure 8c show that the unmodified electrode (SPE, black dots) exhibits the shape of a wide semicircle, indicating that the electrochemical process was dominated by electron transfer and the intrinsic resistance of the electrode is high. Then, the deposition of AuNPs modified the electrical behavior and a smaller semicircle is formed (red dots), indicating a decrease in the resistance of the electrode.

It was observed that the recognition molecule has the ability to modify the electrochemical properties of the surface of the WE as evidenced in the decrease of maximum of current in SWV (blue curve in Figure 8b). Moreover, the Nyquist diagram in Figure 8d (blue dots) reveals that the dative gold-sulphur (Au-S) bond disturbs the existing double layer at the electrode/electrolyte interface, generating a change in capacitance and increasing the electron transfer resistance [32,33]. These signal variations allow us to infer that the PEPTIR1.0 was able to change the diffusion phenomena of the ions present between the electrolyte solution and the electrode, which is associated with the successful immobilization of the molecule on the WE [34].

\subsection{Evaluation of the Biosensor towards Detection of E. coli}

\subsubsection{Evaluation of the Linear Response Range of the Biosensor}

The biosensor obtained was evaluated in the detection of different concentrations $(0$, $10,100,500$ and $1000 \mathrm{CFU} / \mathrm{mL}$ ) of E. coli. The electrochemical response was monitored by electrochemical impedance spectroscopy (EIS) in the presence of $\left[\mathrm{Fe}(\mathrm{CN})_{6}\right]^{-3 /-4}$ couple as redox indicator. (Figure 9, left) shows the Nyquist diagram obtained from the EIS. These results were fitted to a Randles circuit (insert in Figure 9, left) to determine the charge transfer resistance $\left(R_{c t}\right)$ and capacitance values in each measurement $[35,36]$. Thus, it was possible to calculate the normalized charge transfer resistance values $\left(\Delta R_{\text {Normalized }}\right)$ that were correlated with the concentration of the bacteria on a logarithmic scale (Figure 9, right). 

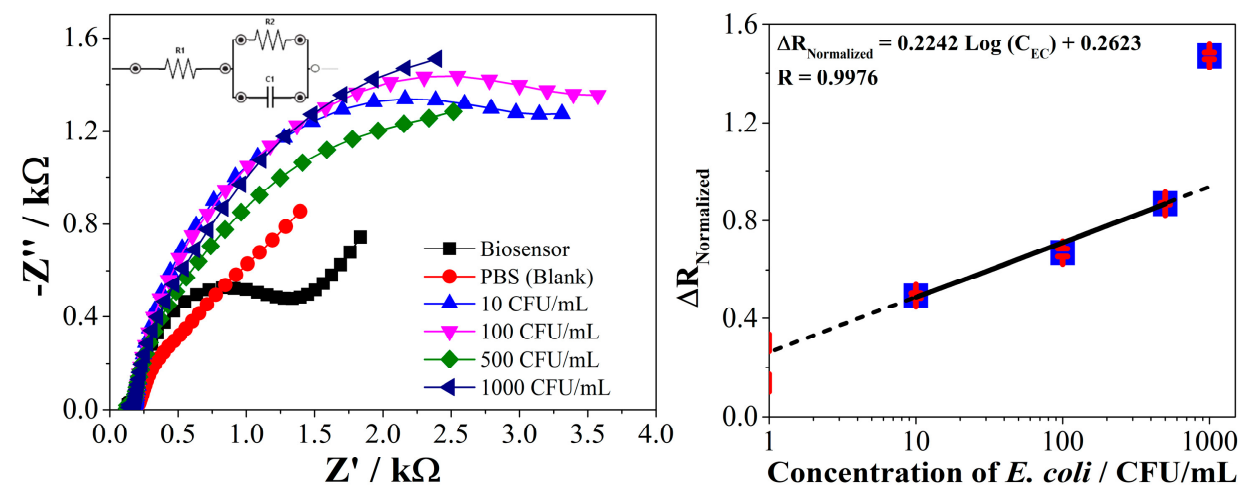

Figure 9. Results of electrochemical detection of E. coli ( 0 to $1000 \mathrm{CFU} / \mathrm{mL}$ ) by using the screenprinted electrodes modified with AuNPs and PEPTIR-1.0 as recognition molecule. (Left): Nyquist diagram of the detection of 0 (blank, PBS), 10, 100, 500 and 1000 CFU/mL of E. coli (insert: Randles circuit used for fitting data). (Right): Correlation of normalized charge transfer resistance values $\left(\Delta \mathrm{R}_{\text {Normalized }}\right)$ with the concentrations of E. coli. $2.0 \mathrm{mM}$ of $\left[\mathrm{Fe}(\mathrm{CN})_{6}\right]^{-3 /-4}$ in $0.1 \mathrm{M}$ of $\mathrm{KCl}$ aqueous solution.

The results show that the blank signal (PBS, red dots in Figure 9, left) modifies the biosensor response, probably due to the interaction of the ions in the buffer solution with the electrode surface. However, the bacteria considerably modify the electrical transport properties of the biosensor from the lowest concentration used $(10 \mathrm{CFU} / \mathrm{mL}$, blue triangles in Figure 9, left), compared to the blank. This is attributed to the formation of a complex between the PEPTIR-1.0 and E. coli through of the Intimin membrane protein, which causes differences in the dielectric or conductivity properties and changing the rate of charge transfer [22]. Finally, it is important to highlight that the electrochemical properties of the negative control of the biosensor (SPE modified with AuNPs but without PEPTIR-1.0) are not modified with the change in the concentration of $E$. coli (see supplementary information for details).

The normalized charge transfer resistance values change linearly with the concentrations of bacteria in a logarithmic scale. The basis from the electrochemical approach is that the interaction between the target bacteria and the PEPTIR-1.0 block the charge transfer of the redox couple from the solution to the surface of the electrode. Nevertheless, the linear behavior is lost at concentrations of $E$. coli above $500 \mathrm{CFU} / \mathrm{mL}$. It can be inferred that the biosensor is saturated with bacteria under the latter condition. It is important to clarify that it is necessary to first evaluate a broad range of concentrations of the analyte of interest before validating an instrument. In this sense, the results show a linear working range for the biosensor based on PEPTIR-1.0 of around 0 to $500 \mathrm{CFU} / \mathrm{mL}$.

It was possible to calculate the approximate limit of detection and quantification (LOD and LOQ) from the following equations:

$$
\begin{aligned}
C_{m} & =\frac{S_{m}-\overline{S_{b l}}}{m}, \\
S_{m} & =\overline{S_{b l}}+k S_{b l},
\end{aligned}
$$

where $C_{m}$ is the limit of detection or quantification, $S_{m}$ is the minimum distinguishable analytical signal, $\overline{S_{b l}}$ is the mean of the response of the blanks, $m$ is the slope of the line, $S_{b l}$ is the standard deviation of the response of the blanks and $k$ is a constant with 3 or 10 value for LOD or LOQ, respectively. Substitution of $S_{m}$ in $C_{m}$ results in

$$
C_{m}=\frac{k S_{b l}}{m} .
$$


The calculated values of LOD and LOQ were 2 and 5 CFU/mL, respectively. These values show a highly response of the biosensor towards $E$. coli. These results contrast with that reported by Malvano, et al., who developed an impedimetric biosensor based on the antimicrobial activity of the peptide nisin for the detection of Salmonella spp. [22]. The authors report that the biosensor obtained is capable of selectively detecting Salmonella spp cells with a detection limit of $15 \mathrm{CFU} / \mathrm{mL}$. On the other hand, Hoyos, et al. reported the design of an impedimetric sensor based on antimicrobial peptides for the early detection of periodontopathogenic bacteria [21]. The system is able to detect $S$. sanguinis in $1 \mathrm{~h}$ with LOD of $10 \mathrm{CFU} / \mathrm{mL}$ in $\mathrm{KCl}$ and $100 \mathrm{CFU} / \mathrm{mL}$ in artificial saliva. In the same context, Liu, et al. (2016) developed a biosensor based on synthetic peptides of modular design for the recognition, detection, and differentiation of pathogenic bacteria, including E. coli [37]. The system showed a detection limit of $100 \mathrm{CFU} / \mathrm{mL}$ of bacteria. According to the above, the system developed in the present study based on AuNPs and PEPTIR-1.0 can be very promising for use in the detection of $E$. coli in aqueous systems. For this, it is necessary to perform a validation of the biosensor in the range of 0 to $500 \mathrm{CFU} / \mathrm{mL}$.

\subsubsection{Evaluation of the Selectivity of the Biosensor}

The selectivity of the biosensor based on PEPTIR-1.0 towards E. coli was evaluated in PBS solutions containing $S$. aureus and $P$. aeruginosa strains. For this, $50 \mathrm{CFU} / \mathrm{mL}$ of each microorganism were used and the changes in the impedimetric response of the biosensor were measured by EIS. The response of the biosensor in terms of percentage of selectivity towards each microorganism is shown in Figure 10.

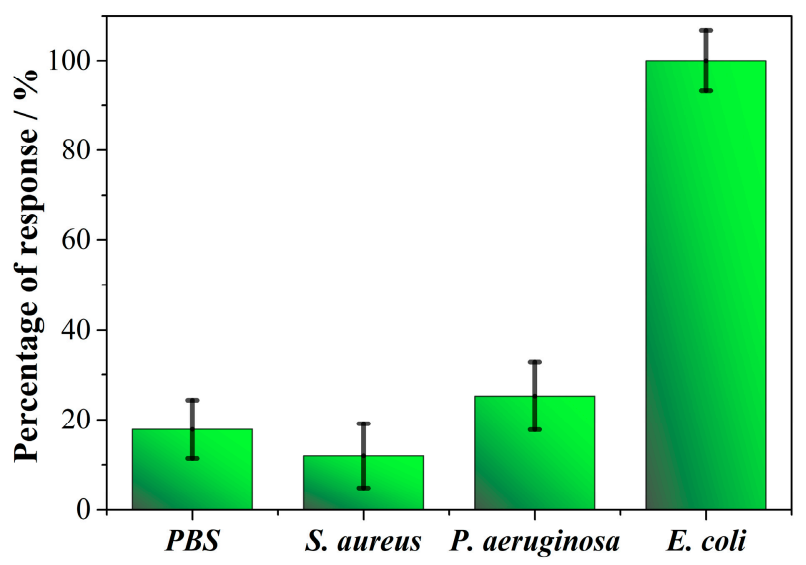

Figure 10. Selectivity results of the biosensor towards the detection of $50 \mathrm{CFU} / \mathrm{mL}$ of E. coli, S. aureus and P. aeruginosa bacteria.

The response of the biosensor to a model gram-positive bacterium such as S. aureus is comparable to blank. On the other hand, there is a slight response of the biosensor towards $P$. aeruginosa in comparison to blank. This can be due to the fact that this microorganism is gram-negative such as E. coli, considering that the biosensor recognizes whole-cells. Despite the above, the signal belonging to the detection of $E$. coli $\left(\Delta \mathrm{R}_{\text {Normalized }}=1.27 \pm 0.19\right.$, see Figure S4 in supplementary information) is higher and significantly different ( $p$-value of 0.0295) than the other bacteria. This is attributed to the fact that the PEPTIR-1.0 molecule was designed to interact with the Intimin membrane protein which is specific of E. coli. Other studies reported the development of an aptamer-based impedimetric biosensor shows a LOD in the detection of E. coli O157:H7 of approximately $100 \mathrm{CFU} / \mathrm{mL}$, with good selective response in the presence of Salmonella typhimurium and Staphylococcus aureus [37]. On the other hand, Yang, et al. developed an impedimetric biosensor without labeling based on a lectin-functionalized self-assembled mixed monolayer, showing a satisfactory selectivity to discriminate $E$. coli from other gram-positive bacteria [38]. 
Therefore, it is important to highlight the capabilities of the biosensor developed in the present study, with excellent LOD and LOQ values, but also the ability to discriminate the presence of E. coli from other bacteria. This make the PEPTIR-1.0-based biosensor a promising system with high reliability for the detection of $E$. coli in aqueous matrices. Finally, it is necessary to carry out studies to evaluate nanostructures that allow to improve the electrical properties of the screen-printed electrode transducer.

\section{Materials and Methods}

\subsection{Reagents, Materials and Instruments}

All reagents were used as received without further purification. Potassium hexacyanoferrate (II) $\left(\mathrm{K}_{4}\left[\mathrm{Fe}(\mathrm{CN})_{6}\right] \times 3 \mathrm{H}_{2} \mathrm{O}, \geq 98 \%\right.$, Merck, Darmstadt, Germany), potassium hexacyanoferrate (III) $\left(\mathrm{K}_{3}\left[\mathrm{Fe}(\mathrm{CN})_{6}\right], \geq 99 \%\right.$, Merck), gold (III) chloride hydrate $\left(\mathrm{HAuCl}_{4}\right.$ $\times 3 \mathrm{H}_{2} \mathrm{O}, \geq 99 \%$, Sigma Aldrich, Saint Louis, MO, USA), potassium chloride $(\mathrm{KCl} \geq 99 \%$, Sigma Aldrich), LB-Agar (Merck).

The peptide PEPTIR-1.0 (sequence QKVNIDELGNAIPSGVLKDD) was synthesized by Biomatik ${ }^{\circledR}$ (Wilmington, DE, USA) with a purity of $>95 \%$. A cysteine was included in the N-terminal region of the chain. The bacterial strains used were the references ATCC 43,895 E. coli O157:H7, ATCC 25,923 S. aureus and ATCC 27,853 P. aeruginosa.

Screen-printed electrodes were acquired commercially (Palmsens) from the manufacturer Italsens, which consists of a working $\left(7.07 \mathrm{~mm}^{2}\right)$, an auxiliary carbon electrode and a silver/silver chloride $(\mathrm{Ag} / \mathrm{AgCl})$ reference electrode.

Electrochemical measurements and evaluation of the biosensor was performed on a potentiostat/galvanostat VersaSTAT 3 (Princeton Applied Research) controlled by Versastudio (v. 2.60.6.) software.

\subsection{Selection of the TIR Protein Interaction Sequence and Its Modeling using Bioinformatics Tools}

From the database RCSB Protein Data Bank the PDB 2ZQK file was obtained, which corresponds to the interaction model of the TIR and Intimin proteins of E. coli O157:H7 proposed by Ma, Y., Zou, Q. and Gao, GF [39]. The three-dimensional structures of the proteins were analyzed through the Chimera software to establish the domains or chains of interest and their possible areas of interaction [40]. Subsequently, through the LigPlot+ program [27], the amino acids that interact by hydrogen bonds and hydrophobic contacts between the Intimin and TIR proteins were selected. For the selected amino acid sequence, simulations were performed using the PEP-FOLD program [41], which is an online system that is based on the concept of the structural alphabet, a set of conformations of elemental prototypes capable of describing all the diversity of protein structures, allowing to perform the 3D reconstruction of peptides. Finally, among the five resulting models, the modeled structure that represented the smallest structural difference with the original A chain of the TIR protein in the 2ZQK model were selected, taking into account the RMSD (for its acronym "Root-mean-square deviation of atomic positions"), obtained from the structural alignment using the command: align name_String1, name_String2 in the PyMol program [42].

\subsection{Selection of Ligands and Docking Molecular between the Peptide and the Intimin E Protein}

From the $2 \mathrm{ZQK}$ model, the A chain was selected, which corresponds to the 3D structure of the Intimin protein. This chain is displayed together with the peptide model (N-chain) previously obtained with the PEP-FOLD program to carry out molecular docking simulations, which refers to the study of the interaction capacity between a ligand (peptide) and a receptor (Intimin protein). These simulations were carried out using Rosetta software, a program that allows, through its Refinement FlexPepDock and FlexPepDock ab-initio protocols, to create complex high-resolution models between peptides and proteins by iteratively optimizing the peptide skeleton and its rigid body orientation relative to the receptor protein [43]. 


\subsection{Preparation and Characterization of the Biosensor}

The electrodeposition of gold nanoparticles (AuNPs) on working electrode (WE) of the screen-printed electrodes (SPEs) was carried out by chronoamperometry (CA) through reducing of a $1.0 \mathrm{mM}$ of $\mathrm{HAuCl}_{4} \times \mathrm{H}_{2} \mathrm{O}$ in $0.5 \mathrm{M}$ of $\mathrm{H}_{2} \mathrm{SO}_{4}$ aqueous solution. Prior to AuNPs deposition, SPEs were previously cleaned with $0.5 \mathrm{M}$ of $\mathrm{H}_{2} \mathrm{SO}_{4}$ and $0.1 \mathrm{M}$ of $\mathrm{KCl}$ solutions by cyclic voltammetry $(\mathrm{CV})$ by applying two cycles between +0.7 and $-0.2 \mathrm{~V}$ and a scan rate of $0.05 \mathrm{~V} / \mathrm{s}$. Then, $100 \mu \mathrm{L}$ of the gold precursor solution were placed on the SPEs and a reduction potential between +0.05 and $-0.25 \mathrm{~V}$ during 20 to $500 \mathrm{~s}$ were applied. The selection of potentials was based on the results obtained by linear sweep voltammetry of the gold precursor solution. The influence of varying the potential and time in chronoamperometry on the response of biosensor were studied.

The peptide selected as a recognition molecule (PEPTIR-1.0) has a cysteine included in the $\mathrm{N}$-terminal region of the chain to induce the formation of a stable S-Au bond with AuNPs. Thereby, the immobilization of the peptide was carried out by chemosorption. For this, $20 \mu \mathrm{L}$ of a PEPTIR-1.0 aqueous solution were placed only on the surface of WE and was left in incubation for $16 \mathrm{~h}$ at $25^{\circ} \mathrm{C}[19,20]$. After that, SPEs were rinsed with ultra-pure water and $0.1 \mathrm{M} \mathrm{KCl}$ aqueous solution. The concentration of PEPTIR-1.0 aqueous solution on the response of biosensor was studied.

Surface structural properties of working electrodes were studied by scanning electron microscopy (SEM) by using a Quanta Field Emission Gun (Model 650) microscope operated at $15.0 \mathrm{kV}$. The images were obtained in secondary electron mode.

The electrochemical properties of the SPEs through each modification with AuNPs and PEPTIR-1.0 were evaluated by cyclic voltammetry (CV), square wave voltammetry (SWV) and electrochemical impedance spectroscopy (EIS), using a potassium hexacyanoferrate (II)/(III) aqueous solution as redox probe and $\mathrm{KCl}(0.1 \mathrm{M})$ as supporting electrolyte $(\mathrm{KCl}$ is necessary for the proper functioning of the pseudo reference electrode). $\mathrm{CV}$ measurements were performed between +0.8 to $-0.4 \mathrm{~V}$ leaving $10 \mathrm{~s}$ of stabilization or equilibrium at $+0.8 \mathrm{~V}$ and a scan rate of $50 \mathrm{mV} / \mathrm{s}$. SWV were performed between -0.4 to $+0.8 \mathrm{~V}$ allowing $10 \mathrm{~s}$ of stabilization or equilibrium at $-0.4 \mathrm{~V}$, the amplitude or "Pulse Height" was $50 \mathrm{mV}$, the potential step ( $\mathrm{E}_{\text {step }}$ ) was $5.0 \mathrm{mV}$ and a frequency of $10 \mathrm{~Hz}$. EIS measurements were performed between 50,000 to $1 \mathrm{~Hz}$ at a fixed potential of $10 \mathrm{mV}$ RMS and $+0.0 \mathrm{~V}$ vs. OCP. CV and SWV were performed using a $10 \mathrm{mM}$ solution of redox probe while EIS measurements were performed using $2.0 \mathrm{mM}$ of redox probe. Figure 11 (steps 1-3) shows the entire biosensor preparation scheme.

\subsection{Detection of E. coli Cells Using the Prepared Electrochemical Biosensor}

Escherichia coli O157:H7 (ATCC 43895) was kept under cryopreservation at $-80{ }^{\circ} \mathrm{C}$ in Luria-Bertani broth (LBB) with $15 \%$ of glycerol. For the reactivation of the microorganism, $50 \mu \mathrm{L}$ of cryopreserved material was added in $5 \mathrm{~mL}$ of LBB and incubated at $35 \pm 2{ }^{\circ} \mathrm{C}$ from 18 to $24 \mathrm{~h}$ before each assay, adjusting the concentration at $1 \times 10^{8} \mathrm{CFU} / \mathrm{mL}$ in $10 \mathrm{mM}$ phosphate buffer solution (PBS) at $\mathrm{pH}$ 7.4.

The evaluation of the biosensor on the detection of E. coli (EC) was performed as described below. $7 \mathrm{~mL}$ of a PBS solution ( $\mathrm{pH}$ 7.4) with known concentrations of EC (10 to $1000 \mathrm{CFU} / \mathrm{mL}$ ) were placed in an appropriate beaker and the biosensor was immersed. The system was incubated at $25^{\circ} \mathrm{C}$ during $30 \mathrm{~min}$ and constant stirring of $150 \mathrm{rpm}$. After that, the biosensor was rinsed with ultra-pure water prior to electrochemical measurements. The detection blank was the PBS solution without bacteria $(0 \mathrm{CFU} / \mathrm{mL}) . \mathrm{CV}, \mathrm{SWV}$ and EIS measurements were performed using the same conditions used for the characterization of the biosensor (Figure 11, step 4, see previous item). 


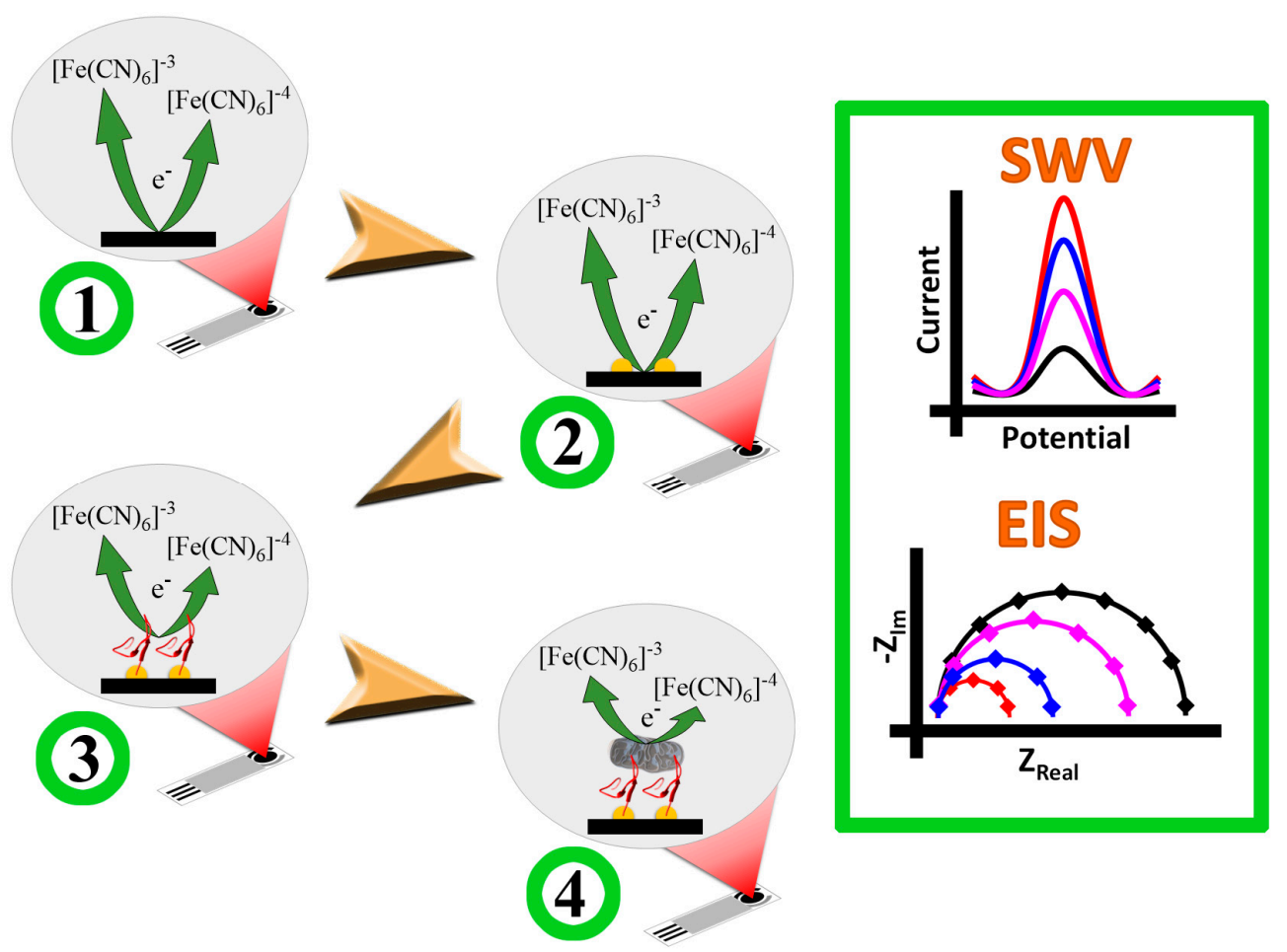

Figure 11. Diagram of the construction of the biosensor and the detection of E. coli. The electrochemical behavior of unmodified (SPE) the electrode in step 1 (left) is schematically represented by black lines in SWV and EIS curves (right). The expected response of the electrode is as follows: SPE/AuNPs (step 2 in left, red lines in SWV and EIS), SPE/AuNPs/PEP (step 3 in left, blue lines in SWV and EIS), and SPE/AuNPs/PEP/EC (step 4 in left, rose lines in SWV and EIS).

The specific interaction of EC with the surface of WE limits the electron charge transfer between redox probe and the transductor. Therefore, current decreases in the case of $\mathrm{CV}$ and SWV and resistance to charge transfer increase in EIS [44]. On the other hand, to verify the ability of PEPTIR-1.0 to show an interaction selectivity, solutions containing different bacteria were tested. In particular, the detection measures were performed in the presence of the strains: ATCC 43,895 E. coli 0157: H7, ATCC 25,923 S. aureus and ATCC 27,853 $P$. aeruginosa, comparing the impedimetric results. The data analyzes to evaluate the EC detection were carried out from SWV and EIS measurements. The current normalized values $\left(\Delta \mathrm{I}_{\text {Normalized }}\right)$ and the resistance normalized values $\left(\Delta \mathrm{R}_{\text {Normalized }}\right)$ were calculated from SWV and EIS results, respectively, using the following equations:

$$
\begin{aligned}
\Delta I_{\text {Normalized }} & =\frac{I_{P E P}-I_{P E P+E C}}{I_{P E P}} \\
\Delta R_{\text {Normalized }} & =\frac{R_{P E P+E C}-R_{P E P}}{R_{P E P}}
\end{aligned}
$$

where $I_{P E P}$ is the maximum current value of the biosensor (electrode modified with AuNPs and PEPTIR-1.0), $I_{P E P+E C}$ is the maximum current value of the biosensor in the detection of bacteria, $R_{P E P}$ is the resistance to charge transfer of the biosensor and $R_{P E P+E C}$ is the resistance to charge transfer in the detection of bacteria. With these results, the current and resistance normalized values were correlated with the concentration of E. coli for establishing criteria such as the detection limit and linearity.

\section{Conclusions}

A new peptide was designed (named PEPTIR-1.0) by bioinformatic tools based on the TIR protein, which is an E. coli receptor protein. PEPTIR-1.0 was used as a recognition 
element in a biosensor based on AuNPs-modified screen-printed electrodes, allowing the sensible and specific detection of $E$. coli in an aqueous matrix.

It was possible to obtain a peptide sequence (QKVNIDELGNAIPSGVLKDD) from the TIR protein that interacts with the Intimin membrane protein through hydrophobic and electrostatic interactions. This sequence was shown to have a conserved three-dimensional structure relative to the original structure in the protein.

On the other hand, it was evidenced that the structural characteristics of the AuNPs obtained by electrodeposition considerably affect the behavior of the biosensor. In addition, it was shown that the applied potential and the electrodeposition time of chronoamperometry are affected simultaneously. For this reason, these two variables must be evaluated simultaneously in each biosensor system.

The biosensor obtained based on PEPTIR-1.0 exhibit a linear working range between 0 to $500 \mathrm{CFU} / \mathrm{mL}$ and limits of detection and quantification of 2 and $6 \mathrm{CFU} / \mathrm{mL}$, respectively. Moreover, the statistically significant differences in the impedimetric responses of the biosensor in the presence of other microorganisms such as S. aureus and P. aeruginosa, highlight the possibility that this new biosensor can be used in the rapid, sensitive, and selective detection of $E$. coli in aqueous matrices.

Supplementary Materials: The following are available online, Table S1. Normalized current values obtained from SWV results for the potential and time used in electrodeposition of AuNPs; Figure S1. Results of SWV of the effect of the applied potential in chronoamperometry for AuNPs electrodeposition at a constant time of $20 \mathrm{~s}$; Figure S2. Results of SWV of the effect of the applied potential in chronoamperometry for AuNPs electrodeposition at a constant time of $250 \mathrm{~s}$.

Author Contributions: J.L.R.-V.: conceptualization, methodology, software, validation, formal analysis, investigation, resources, data-curation, writing-review and editing, supervision, project administration, funding acquisition; J.F.R.-O.: conceptualization, methodology, software, validation, formal analysis, investigation, data-curation, writing-original draft preparation; Y.J.G.-C.: methodology, validation, formal analysis, investigation, data-curation, writing-original draft preparation; P.R.-V.: conceptualization, methodology, software, validation, formal analysis, investigation, data-curation, writing-review and editing, supervision; J.M.F.-C.: conceptualization, methodology, software, validation, formal analysis, investigation, resources, data-curation, writing-review and editing, supervision, funding acquisition. All authors have read and agreed to the published version of the manuscript.

Funding: This research was supported by MINCIENCIAS under grant number CT 596-2018.

Institutional Review Board Statement: Not applicable.

Informed Consent Statement: Not applicable.

Data Availability Statement: Not applicable.

Acknowledgments: P. Rondón-Villarreal thanks COLCIENCIAS for the doctoral scholarship in the frame of the program "Convocatoria nacional para estudios a nivel de doctorado en Colombia-año 2010".

Conflicts of Interest: The authors declare no conflict of interest.

Sample Availability: Samples of the PEPTIR-1.0 are available from the authors.

\section{References}

1. Kirk, M.D.; Pires, S.M.; Black, R.E.; Caipo, M.; Crump, J.A.; Devleesschauwer, B.; Döpfer, D.; Fazil, A.; Fischer-Walker, C.L.; Hald, T.; et al. World Health Organization Estimates of the Global and Regional Disease Burden of 22 Foodborne Bacterial, Protozoal, and Viral Diseases, 2010: A Data Synthesis. PLoS Med. 2015, 12, e1001921. [CrossRef]

2. Hald, T.; Aspinall, W.; Devleesschauwer, B.; Cooke, R.; Corrigan, T.; Havelaar, A.H.; Gibb, H.J.; Torgerson, P.R.; Kirk, M.D.; Angulo, F.j; et al. World Health Organization Estimates of the Relative Contributions of Food to the Burden of Disease Due to Selected Foodborne Hazards: A Structured Expert Elicitation. PLoS ONE 2016, 11, e0145839. [CrossRef]

3. Gracias, K.S.; McKillip, J.L. A review of conventional detection and enumeration methods for pathogenic bacteria in food. Can. J. Microbiol. 2004, 50, 883-890. [CrossRef]

4. Abbaspour, A.; Norouz-Sarvestani, F.; Noori, A.; Soltani, N. Aptamer-conjugated silver nanoparticles for electrochemical dual-aptamer-based sandwich detection of staphylococcus aureus. Biosens. Bioelectron. 2015, 68, 149-155. [CrossRef] [PubMed] 
5. Shih, C.-M.; Chang, C.-L.; Hsu, M.-Y.; Lin, J.-Y.; Kuan, C.-M.; Wang, H.-K.; Huang, C.-T.; Chung, M.-C.; Huang, K.-C.; Hsu, C.-E.; et al. Paper-based ELISA to rapidly detect Escherichia coli. Talanta 2015, 145, 2-5. [CrossRef] [PubMed]

6. Liu, Y.; Singh, P.; Mustapha, A. High-resolution melt curve PCR assay for specific detection of E. coli O157:H7 in beef. Food Control 2018, 86, 275-282. [CrossRef]

7. Sharma, L.; Watts, E.; Singh, P. High resolution real-time PCR melting curve assay for identification of top five Penaeidae shrimp species. LWT 2020, 133, 109983. [CrossRef]

8. Chen, S.; Zhao, S.; McDermott, P.F.; Schroeder, C.M.; White, D.G.; Meng, J. A DNA microarray for identification of virulence and antimicrobial resistance genes in Salmonella serovars and Escherichia coli. Mol. Cell. Probes 2005, 19, 195-201. [CrossRef] [PubMed]

9. Kosack, C.S.; Page, A.-L.; Klatser, P.R. A guide to aid the selection of diagnostic tests. Bull. World Health Organ. 2017, 95, 639-645. [CrossRef]

10. Hajihosseini, S.; Nasirizadeh, N.; Hejazi, M.S.; Yaghmaei, P. A sensitive DNA biosensor fabricated from gold nanoparticles and graphene oxide on a glassy carbon electrode. Mater. Sci. Eng. C 2016, 61, 506-515. [CrossRef] [PubMed]

11. Bachan Upadhyay, L.S.; Verma, N. Enzyme Inhibition Based Biosensors: A Review. Anal. Lett. 2012, 46, 225-241. [CrossRef]

12. Zhao, S.; Wen, H.; Ou, Y.; Li, M.; Wang, L.; Zhou, H.; Di, B.; Yu, Z.; Hu, C. A new design for living cell-based biosensors: Microgels with a selectively permeable shell that can harbor bacterial species. Sens. Actuators B Chem. 2021, 334, 129648. [CrossRef]

13. Vanova, V.; Mitrevska, K.; Milosavljevic, V.; Hynek, D.; Richtera, L.; Adam, V. Peptide-based electrochemical biosensors utilized for protein detection. Biosens. Bioelectron. 2021, 180, 113087. [CrossRef]

14. Kaya, H.O.; Cetin, A.E.; Azimzadeh, M.; Topkaya, S.N. Pathogen detection with electrochemical biosensors: Advantages, challenges and future perspectives. J. Electroanal. Chem. 2021, 882, 114989. [CrossRef] [PubMed]

15. Castro-Ortiz, L.P.; Luna Pabello, V.M.; Villalobos Pietrini, R. Estado del arte y perspectivas del uso de biosensores ambientales en México. Rev. Int. Contam. Ambient. 2007, 23, 35-45.

16. Wei, Z.; Cai, X.; Zhang, J.; Fan, J.; Xu, J.; Xu, L. High Sensitive Immunoelectrochemical Measurement of Lung Cancer Tumor Marker ProGRP Based on TiO2-Au Nanocomposite. Molecules 2019, 24, 656. [CrossRef] [PubMed]

17. Dong, J.; Zhao, H.; Xu, M.; Ma, Q.; Ai, S. A label-free electrochemical impedance immunosensor based on AuNPs/PAMAMMWCNT-Chi nanocomposite modified glassy carbon electrode for detection of Salmonella typhimurium in milk. Food Chem. 2013, 141, 1980-1986. [CrossRef] [PubMed]

18. Li, Y.; Afrasiabi, R.; Fathi, F.; Wang, N.; Xiang, C.; Love, R.; She, Z.; Kraatz, H.-B. Impedance based detection of pathogenic E. coli O157:H7 using a ferrocene-antimicrobial peptide modified biosensor. Biosens. Bioelectron. 2014, 58, 193-199. [CrossRef] [PubMed]

19. Jing, P.; Yi, H.; Xue, S.; Yuan, R.; Xu, W. A 'signal on-off' electrochemical peptide biosensor for matrix metalloproteinase 2 based on target induced cleavage of a peptide. RSC Adv. 2015, 5, 65725-65730. [CrossRef]

20. Rodovalho, V.R.; Araujo, G.R.; Vaz, E.R.; Ueira-Vieira, C.; Goulart, L.R.; Madurro, J.M.; Brito-Madurro, A.G. Peptide-based electrochemical biosensor for juvenile idiopathic arthritis detection. Biosens. Bioelectron. 2018, 100, 577-582. [CrossRef]

21. Hoyos-Nogués, M.; Brosel-Oliu, S.; Abramova, N.; Bratov, A.; Mas-Moruno, C.; Gil, F.J. Sensor impedimétrico para la detección de bacterias patogénicas mediante péptidos antimicrobianos. Biomecánica 2018, 24, 32-38. [CrossRef]

22. Malvano, F.; Pilloton, R.; Albanese, D. A novel impedimetric biosensor based on the antimicrobial activity of the peptide nisin for the detection of Salmonella spp. Food Chem. 2020, 325, 126868. [CrossRef]

23. Zhang, J.; Cao, Y. Peptide-Based Biosensors. In Nano-Inspired Biosensors for Protein Assay with Clinical Applications; Elsevier: Amsterdam, The Netherlands, 2019; pp. 167-185. ISBN 9780128150535.

24. Karimzadeh, A.; Hasanzadeh, M.; Shadjou, N.; Guardia, M. De la Peptide based biosensors. TrAC Trends Anal. Chem. 2018, 107, 1-20. [CrossRef]

25. Farfán-García, A.E.; Ariza-Rojas, S.C.; Vargas-Cárdenas, F.A.; Vargas-Remolina, L.V. Mecanismos de virulencia de Escherichia coli enteropatógena. Rev. Chil. Infectología 2016, 33, 438-450. [CrossRef] [PubMed]

26. DeVinney, R.; Stein, M.; Reinscheid, D.; Abe, A.; Ruschkowski, S.; Finlay, B.B. Enterohemorrhagic Escherichia coliO157:H7 Produces Tir, Which Is Translocated to the Host Cell Membrane but Is Not Tyrosine Phosphorylated. Infect. Immun. 1999, 67, 2389-2398. [CrossRef] [PubMed]

27. Laskowski, R.A.; Swindells, M.B. LigPlot+: Multiple Ligand-Protein Interaction Diagrams for Drug Discovery. J. Chem. Inf. Model. 2011, 51, 2778-2786. [CrossRef]

28. Xue, L.C.; Rodrigues, J.P.; Kastritis, P.L.; Bonvin, A.M.; Vangone, A. PRODIGY: A web server for predicting the binding affinity of protein-protein complexes. Bioinformatics 2016, 32, btw514. [CrossRef]

29. Rosetta Interface Analyzer. Available online: https://new.rosettacommons.org/docs/latest/application_documentation/ analysis/interface-analyzer (accessed on 10 February 2021).

30. Kanyong, P.; Rawlinson, S.; Davis, J. Gold nanoparticle modified screen-printed carbon arrays for the simultaneous electrochemical analysis of lead and copper in tap water. Microchim. Acta 2016, 183, 2361-2368. [CrossRef]

31. López-Lorente, Á.I.; Valcárcel, M.; López-Lorente, Á.I. Gold Nanoparticles in Analytical Chemistry, 1st ed.; Elsevier: Amsterdam, The Netherlands, 2014; ISBN 9780444632852.

32. Majzik, A.; Fülöp, L.; Csapó, E.; Bogár, F.; Martinek, T.; Penke, B.; Bíró, G.; Dékány, I. Functionalization of gold nanoparticles with amino acid, $\beta$-amyloid peptides and fragment. Colloids Surfaces B Biointerfaces 2010, 81, 235-241. [CrossRef]

33. Labib, M.; Zamay, A.S.; Kolovskaya, O.S.; Reshetneva, I.T.; Zamay, G.S.; Kibbee, R.J.; Sattar, S.A.; Zamay, T.N.; Berezovski, M.V. Aptamer-Based Impedimetric Sensor for Bacterial Typing. Anal. Chem. 2012, 84, 8114-8117. [CrossRef] [PubMed] 
34. Castillo, G.; Pribransky, K.; Mező, G.; Kocsis, L.; Csámpai, A.; Németh, K.; Keresztes, Z.; Hianik, T. Electrochemical and Photometric Detection of Plasmin by Specific Peptide Substrate. Electroanalysis 2015, 27, 789-798. [CrossRef]

35. Puiu, M.; Bala, C. Peptide-based electrochemical biosensors. In Electrochemical Biosensors; Elsevier: Amsterdam, The Netherlands, 2019; pp. 277-306. ISBN 9780128164914.

36. Rezaei, B.; Irannejad, N. Electrochemical detection techniques in biosensor applications. In Electrochemical Biosensors; Elsevier: Amsterdam, The Netherlands, 2019; pp. 11-43. ISBN 9780128164914.

37. Brosel-Oliu, S.; Ferreira, R.; Uria, N.; Abramova, N.; Gargallo, R.; Muñoz-Pascual, F.X.; Bratov, A. Novel impedimetric aptasensor for label-free detection of Escherichia coli O157:H7. Sens. Actuators B Chem. 2018, 255, 2988-2995. [CrossRef]

38. Yang, H.; Zhou, H.; Hao, H.; Gong, Q.; Nie, K. Detection of Escherichia coli with a label-free impedimetric biosensor based on lectin functionalized mixed self-assembled monolayer. Sens. Actuators B Chem. 2016, 229, 297-304. [CrossRef]

39. Yi, Y.; Ma, Y.; Gao, F.; Mao, X.; Peng, H.; Feng, Y.; Fan, Z.; Wang, G.; Guo, G.; Yan, J.; et al. Crystal Structure of EHEC Intimin: Insights into the Complementarity between EPEC and EHEC. PLoS ONE 2010, 5, e15285. [CrossRef] [PubMed]

40. Pettersen, E.F.; Goddard, T.D.; Huang, C.C.; Couch, G.S.; Greenblatt, D.M.; Meng, E.C.; Ferrin, T.E. UCSF Chimera: A visualization system for exploratory research and analysis. J. Comput. Chem. 2004, 25, 1605-1612. [CrossRef] [PubMed]

41. Maupetit, J.; Derreumaux, P.; Tuffery, P. PEP-FOLD: An online resource for de novo peptide structure prediction. Nucleic Acids Res. 2009, 37, W498-W503. [CrossRef]

42. The PyMOL Molecular Graphics System, Version Open-Source PyMOL 1.8.x., Schrödinger, LLC. Available online: https: / / github.com/schrodinger/pymol-open-source (accessed on 11 September 2020).

43. Raveh, B.; London, N.; Schueler-Furman, O. Sub-angstrom modeling of complexes between flexible peptides and globular proteins. Proteins Struct. Funct. Bioinform. 2010, 78, 2029-2040. [CrossRef]

44. Brosel-Oliu, S.; Uria, N.; Abramova, N.; Bratov, A. Impedimetric Sensors for Bacteria Detection. In Biosensors—Micro and Nanoscale Applications; InTechOpen: London, UK, 2015. 